\title{
Variation in recruitment does not drive the cline in diversity along an estuarine gradient
}

\author{
Megan N. Dethier* \\ Friday Harbor Laboratories and Department of Biology, University of Washington, Friday Harbor, Washington 98250, USA
}

\begin{abstract}
Spatial pattern and intensity of recruitment have substantial effects on adult community structure in some but not all marine systems. Such 'supply-side' effects have been relatively poorly studied in soft-sediment habitats because of the difficulty of sampling very small infaunal recruits. I investigated whether spatial patterns of infaunal recruitment along an estuarine gradient could account for the observed cline in adult diversity. On 9 occasions spread over 13 mo, cores of sterile sediment from 2 different sources were embedded in beaches along the estuarine axis of Puget Sound, Washington, and sampled 6 wk later for new recruits. Identities and abundances of recruits (mostly polychaetes and bivalves) varied among seasons, but differed little between sediments from different sources. Contrary to expectations, neither recruit richness nor abundance was lower at the southern (more estuarine) end of the gradient, where adult taxonomic diversity is low. For a number of taxa and time periods, recruitment was actually stronger at the southern beaches. Multivariate differences between assemblages of recruits and adults were much greater at the southern sites, indicating that post-recruitment processes at these sites modify diversity and abundance patterns initially established by recruitment. These processes could include predation on juveniles, adult-juvenile competition, or physiologically stressful abiotic conditions.
\end{abstract}

KEY WORDS: Recruitment $\cdot$ Soft-sediment $\cdot$ Infauna $\cdot$ Estuarine $\cdot$ Supply-side $\cdot$ Polychaetes $\cdot$ Clams Resale or republication not permitted without written consent of the publisher

\section{INTRODUCTION}

Marine ecologists continue to debate the conditions under which local communities are structured by temporal and spatial patterns of recruitment (supply-side) versus processes acting after recruitment. Patterns of recruitment can be influenced by abundance of propagules, currents that affect transport and dispersal, availability of habitat suitable for settlement, ability of propagules to access that habitat, and early postsettlement survival; all are likely to be important at some scales (Caley et al. 1996, Fraschetti et al. 2002, Navarrete et al. 2008). Key factors affecting recruitment can differ along natural gradients in oceanographic conditions (e.g. upwelling regimes), physical stress, and predation pressure. In rocky habitats there are documented cases of the roles of both supply-side factors (Bellgrove et al. 1997, Wing et al. 2003) and post-recruitment factors (reviewed in Caley et al. 1996,
Blanchette \& Gaines 2007, Freidenburg et al. 2007, Rilov et al. 2008). In soft sediments, including many habitats in estuaries, both larval supply and behavior and also later interactions can dictate community composition of adults (e.g. Olafsson et al. 1994, Snelgrove \& Butman 1994, Lu \& Wu 2007, Thomsen et al. 2007).

A feasible way to test for the role of recruitment limitation in structuring communities is to document patterns of recruitment and determine how well these match the variation in adult assemblages. In soft-sediment communities, local recruitment may be affected by grain size and sediment chemistry, which in turn can be influenced by resident organisms (e.g. Hockin 1982, Snelgrove \& Butman 1994, Wu \& Shin 1997, Marinelli \& Woodin 2004, Beukema \& Dekker 2005). Polluted sediments may affect settlement (Lenihan et al. 2003, Stark et al. 2004, Lu \& Wu 2006), although it is difficult to distinguish this effect from early mortality. On larger scales, sites with good recruitment may be 
consistent from year to year, suggesting local flow regimes that allow larvae to disperse to those areas and settle out of the plankton effectively (reviewed in Olafsson et al. 1994, Snelgrove \& Butman 1994, Fraschetti et al. 2002, also Wu \& Shin 1997, Hunt et al. 2003). Nevertheless, sites with consistently high recruitment do not necessarily have large adult populations, illustrating the intervention of post-recruitment mortality (Olafsson et al. 1994). Predation on and bioturbation of larvae and juveniles can reduce abundance and impose new patterns on adult assemblages (e.g. Beukema \& Dekker 2005, Pillay et al. 2007); however, experiments on these processes are often confounded by cage artifacts (Peterson 1979). Food subsidies for recruits are thought to affect growth more than survival (Peterson 1982, Olafsson et al. 1994), although food resource levels in surface sediments may affect both larval settlement behavior and subsequent survivorship. Abiotic factors such as sediment movement or physiologically stressful conditions can also affect survival (e.g. Labrune et al. 2007).

Few field studies in soft sediments have quantified settlement per se (propagules reaching the bottom at a site) because of the difficulty of sampling very small infauna (Smith \& Brumsickle 1989, Hunt et al. 2003, Reiss \& Kroncke 2005), so patterns of recruitment (which incorporates early post-settlement mortality) are typically assumed to be indicative of patterns of settlement. Distinguishing between these 2 processes is further complicated by the fact that infauna may be passively or actively redistributed after settlement. Waves and tidal currents, even in protected estuaries, erode juvenile clams and worms out of sediments and disperse them to other areas (Shull 1997, Hunt et al. 2003, Lundquist et al. 2004, 2006, Negrello Filho et al. 2006, Hunt et al. 2007, St-Onge \& Miron 2007). This bedload transport may be actively used by mobile worms and by bivalves forming mucus threads (Sigurdsson et al. 1976, Jennings \& Hunt 2009), and is especially important for species without planktonic development (Shull 1997). In addition, adults or juveniles may redistribute themselves locally by simply crawling laterally through the sediment (Whitlatch et al. 1998, Negrello Filho et al. 2006).

Patterns of species diversity in soft sediments, like other aspects of community structure, may be controlled by variable recruitment or by subsequent processes. In estuaries, species diversity of soft-sediment benthic communities is consistently lower in the inner (less marine) portions, even in studies where substrate types and other factors are controlled (Dethier \& Schoch 2005, and references therein). Except for highly mobile nekton, for a marine species with dispersive propagules to be consistently absent in an area such as an inner estuary, there must be either contin- ued failure of settlement or early mortality. The scale of a given pattern of distribution gives an indication of the possible mechanisms, e.g. predation on young recruits at a few sites versus mortality caused by low salinity in a whole region (Caley et al. 1996). Similarly, lack of dispersal of propagules to an inner estuary because of circulation anomalies could cause a largescale diversity gradient.

Puget Sound, Washington, is a large fjordal estuary with physical gradients that are subtle relative to many estuaries (salinity ca. 4 psu lower and temperature ca. $2^{\circ} \mathrm{C}$ higher in nearshore waters in the inner Sound) (Dethier \& Schoch 2005). However, a striking diversity pattern exists among pebble-sand beaches along this extensive shoreline with much lower species richness at inner (southern) sites than at more marine (northern) sites, both for epibiota and for infauna (Dethier \& Schoch 2005). This diversity pattern is consistent from year to year (see 'Results') and is accompanied by a similar gradient in biomass (Dethier et al. 2010). I hypothesized that this diversity pattern occurs because the inner parts of Puget Sound suffer annual failures in recruitment due to poor dispersal there or to presettlement mortality of larvae caused by the moreestuarine conditions in the water column. I tested this hypothesis by monitoring recruitment of infauna through the year at a range of beaches along the estuarine gradient.

\section{MATERIALS AND METHODS}

Infaunal recruitment was sampled at 3 of the 15 pebble-sand sites described in Dethier \& Schoch (2005), spanning $83 \mathrm{~km}$ of the north-south geographic gradient. These sites were located in the southern (Budd), south-central (Brown), and north-central (Carkeek; nearest the mouth of the estuary) regions of Puget Sound (Fig. 1). Three beaches (North, Middle, and South) were sampled at each site.

Recruitment of invertebrates into experimental cylinders filled with sediment was quantified at ca. $6 \mathrm{wk}$ intervals at all 9 beaches for 13 mo ( 9 dates between June 2005 and June 2006). Using this sampling interval, I was unable to distinguish actual settlement differences from very early post-settlement survival, but I attempted to control some sources of early mortality such as predation. Recruitment samplers were constructed of $1 \mathrm{~mm}$ mesh nylon window screening (cylinders 9 to $10 \mathrm{~cm}$ diameter and $15 \mathrm{~cm}$ tall, with a screen bottom attached with hot melt glue) that allowed normal pore water movement but limited access by infaunal predators. Cylinders were buried flush with the surrounding sediment at Mean Lower Low Water (MLLW), the same elevation used by Dethier \& Schoch (2005). To 


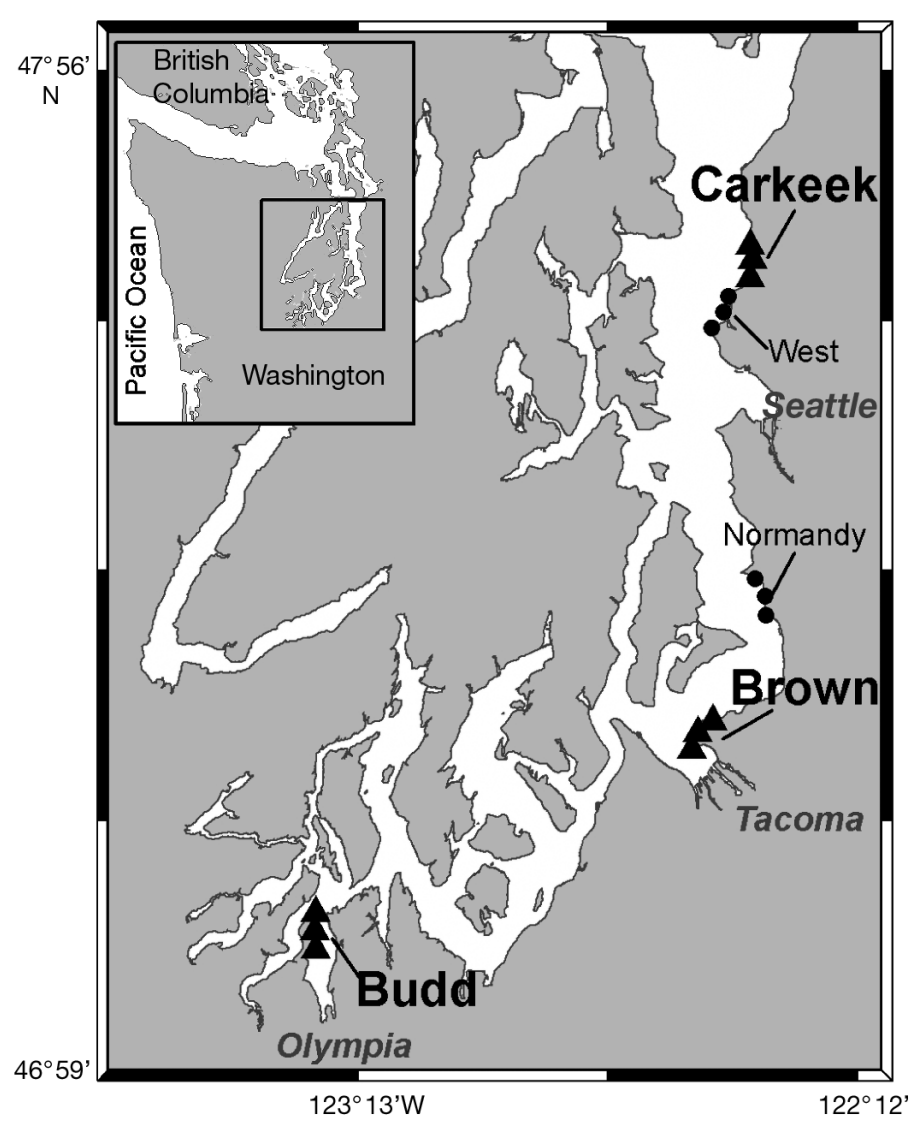

Fig. 1. Puget Sound. Main experimental sites (in large bold) where infaunal recruitment was quantified in experimental cylinders at 3 beaches $(\boldsymbol{\Delta})$. ( $(\bullet)$ indicates beaches where unmanipulated sediment was sampled in June 2005

compare recruitment in sediment that might vary in grain size or chemistry, cylinders were filled with sediment collected from one of 2 sites: Brown North (where the surface sediment had more cobbles) and Budd North (which appeared finer) (Dethier \& Schoch 2005). In each case, the sediment was a mix of pebbles and sand, excluding pebbles $>3 \mathrm{~cm}$ in diameter; native macrofauna was killed by freezing. Per beach 5 replicate cylinders were used for each sediment type at the north and south sites (only Brown North sediment was used at Brown because of time limitations). Grain sizes at the 2 source areas were quantified in April, July, and December 2005; 5 samples of surface sediment (to $\sim 6 \mathrm{~cm}$ depth) were collected at MLLW at each beach, pebbles $>3 \mathrm{~cm}$ were removed, and the remainder was dry-sieved (Dethier et al. 2010).

Recruitment into each cylinder was quantified $6 \mathrm{wk}$ after emplacement by collecting $100 \mathrm{ml}$ samples of surface sediment (ca. the top $2 \mathrm{~cm}$ ) from each and replacing it with new defaunated sediment from the same frozen stocks. Samples were returned to the lab for processing. Each sample was added to $1.5 \mathrm{l}$ of seawater and stirred rapidly to suspend small organisms, then poured quickly through a $100 \mu \mathrm{m}$ mesh sieve (methods adapted from Shull 1997, Hunt et al. 2003). Remaining coarser sediments were washed through $2 \mathrm{~mm}$ and $1 \mathrm{~mm}$ sieves; contents of these were examined for heavier recruits (especially small clams) that were not suspended during stirring. Fine material (sediment and organisms retained on the $100 \mu \mathrm{m}$ sieve) was washed gently into a $20 \mathrm{ml}$ sample vial and preserved in $5 \%$ formalin.

To enumerate and identify smaller recruits, I decanted the formalin from the vials, stained the contents with Rose Bengal in seawater, and examined them under a dissecting microscope. 'Recruits' were defined as segmented worms, bivalves, and echinoderms 0.1 to $10 \mathrm{~mm}$ in length. I did not count highly mobile or larger organisms that likely had traveled into the cylinder from surrounding sediment (e.g. Nucella, nematodes, capitellids, all crustaceans). A few taxa (e.g. the archiannelid Nerilla, chrysopetalid polychaetes, the clam Rochefortia tumida) probably never grow $>1 \mathrm{~cm}$ and thus might not all have been newly settled from the plankton. For these, I either only counted smaller individuals (e.g. Rochefortia $<4 \mathrm{~mm}$ ) or omitted the taxon from comparisons with adult fauna. Some polychaetes could be identified to species (Appendix 1) but others only to family; most clams were identified to species (except for some individuals $<1 \mathrm{~mm}$, grouped as 'small clams').

To compare recruitment into experimental cylinders with that into unmanipulated sediment at nearby sites, I collected 5 similar $100 \mathrm{ml}$ surface-sediment samples from MLLW at each of 3 beaches at 2 additional sites between Brown and Carkeek in June 2005 (Normandy and West; Fig. 1). Recruits were separated and enumerated in the same way, and compared with samples from the experimental beaches from the same month using multivariate analyses (described below).

To compare species and abundances of adults found in unmanipulated sediment with recruits found at the same beaches, I compared the assemblages of recruits from the cylinders (from June 2005 to June 2006, with abundances of each species or taxon averaged among the 9 samples) with adult assemblages sampled in June 2004, 2005, and 2006. Adult infauna were sampled along transects at MLLW with 10 cores per beach (10 $\mathrm{cm}$ diameter, $15 \mathrm{~cm}$ deep) sieved to $2 \mathrm{~mm}$ (Dethier \& Schoch 2005); smaller mesh sizes completely clog with this pebble-sand sediment type. To compare assemblages, I eliminated from the recruit database those taxa whose adults were smaller than $2 \mathrm{~mm}$. Adult infauna were divided into the same taxonomic categories (e.g. polychaete families) used for recruits (Appendix 1). 
For 3 high-recruitment (summer) and 2 low-recruitment (fall-winter) months, split-plot ANOVAs (with main factors Sediment and Site, and with Beaches nested within Sites; Systat 9) were used to compare total abundances and taxon richness of infaunal recruits at Budd and Carkeek. Counts were $(\log +1)$ transformed if plotted residuals were skewed. For parameters with no significant Sediment effect, data from the 2 sediment sources were pooled and all 3 sites (including Brown, where only 1 type of sediment was used) were tested for Site and Beach effects. For some analyses, I also examined clam recruitment separately because clams were abundant, and some clam species are recreationally important. Multivariate analyses using PRIMER 6 and PERMANOVA examined spatial and temporal patterns of the whole recruit assemblage (square-root transformed abundances for each taxon), compared recruitment in natural and experimental sediment, and compared recruit assemblages with local adult assemblages.

\section{RESULTS}

In total, almost 16000 recruits belonging to 56 taxa were found, dominated by polychaetes $(48 \%$ of taxa, $68 \%$ of individuals) and bivalves (30\% of taxa and individuals) (Appendix 1). Both richness (Fig. 2a) and abundance (Fig. 2b) of recruits varied through the year; highest values occurred in the summer and early fall, following the late-spring plankton blooms that sustain many larvae (Strathmann 1987). However, for some species such as the common clam Macoma inquinata, some recruitment (presence of clams $<2 \mathrm{~mm}$ ) was seen year-round (data not shown). The June 2006 samples had fewer and less diverse recruits than the June 2005 samples (Fig. 2a,b). Recruitment in most months was dominated by carnivores (primarily hesionids) (Fig. 2b, Appendix 1), suspension feeders (various clams), surfacedeposit-feeding Macoma clams, and subsurface deposit-feeders (especially the opheliid Armandia), with no apparent trophic pattern across seasons. No signifi- a) Number of taxa recruiting per site

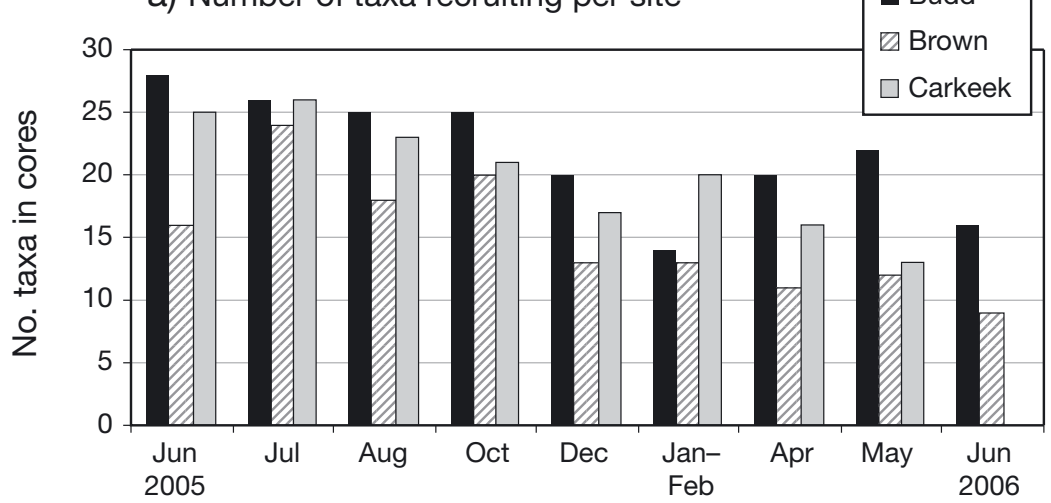

b) Recruits by trophic group

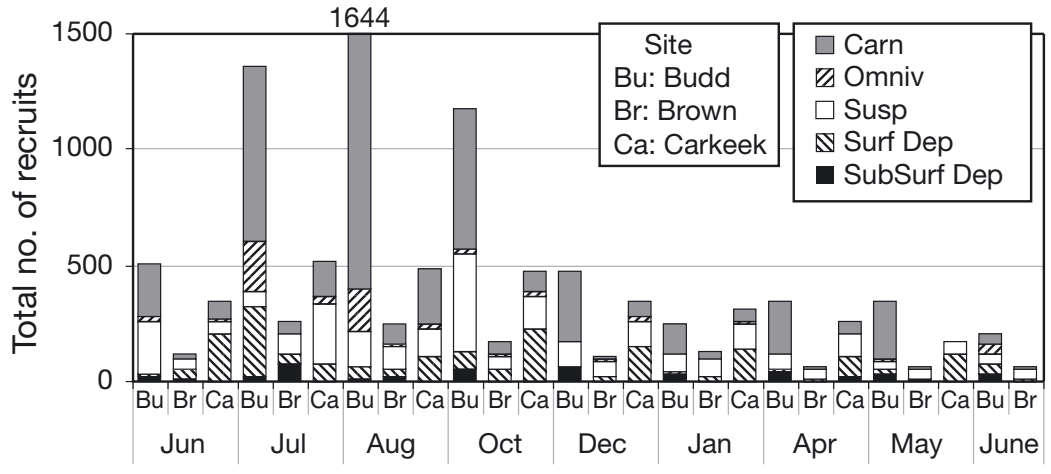

c) Hesionids at Budd (total in 30 samples)

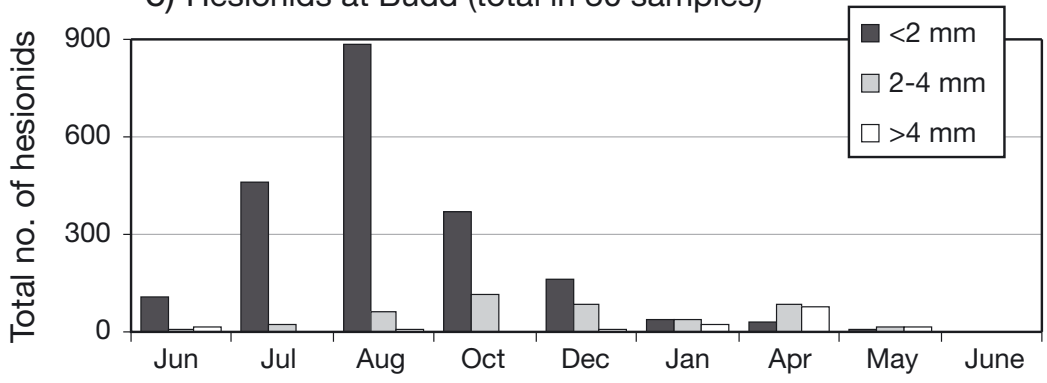

Fig. 2. Seasonal patterns of recruitment into experimental cylinders. Sediment treatments are pooled. June 2006 samples from Carkeek were poorly preserved and are not included in analyses. (a) Number of taxa recruiting per site (in all cylinders). (b) Total number of recruits per site, grouped by trophic category (see Appendix 1). Each bar represents the summed number of individuals in the 30 cylinders per site $(5$ cylinders per sediment source per beach $\times 2$ sources $\times$ 3 beaches). (c) Number of individuals in each of 3 size categories of hesionid (the most abundant polychaete family) at Budd Inlet

cant differences between sites or months were seen when recruits were categorized by larval longevity (data not shown). Most recruiting taxa appear to spend at least 1 to $2 \mathrm{wk}$ in the plankton (Appendix 1), although time until settlement in the laboratory has only been quantified for a few of these local taxa (Strath- 
mann 1987). For most of the taxa, the smallest size class $(<2 \mathrm{~mm})$ was the most common (e.g. Fig. $2 \mathrm{c})$; adult sizes of these taxa range from 10 to $>150 \mathrm{~mm}$, so the counted individuals were either newly settled or young juveniles. For many taxa, early settlers as small as $1 \mathrm{~mm}$ were found (e.g. 8-setiger glycerids).

In 2-way ANOVAs (for fixed factors Site and Sediment), sediment source (Budd vs. Brown) showed very few effects on richness or abundance of recruits, either for all taxa or for clams analyzed separately ( 2 marginally significant results in Table 1; June 2005 richness results in Fig. 3a). However, significant Sediment $\times$ Site interactions were found for 2 parameters (Table 1): recruit richness in January (when 'Brown' sediment had more taxa at Carkeek than 'Budd' sediment, but 'Budd' sediment had more taxa than 'Brown' sediment at Budd) and clam abundance in October (same pattern). I anticipated that the grain sizes in the Brown-source sediment would be coarser than the Budd-source sediment because wave energies are slightly higher at Brown, and there is more surface cobble (Dethier \& Schoch 2005); however, grain sizes were very similar. Coarse sediment (small pebbles 1 to $30 \mathrm{~mm}$ ) comprised $\sim 17 \%$ of the total dry mass at each site. Of the fine fraction ( $<1 \mathrm{~mm}$ ), both sites had $~ 80 \%$ by weight Phi 1 plus 2 (coarse to medium sand), with $<1 \%$ fines and $<1 \%$ organics.

Significant Site effects on recruitment were seen in only 4 of 16 analyses (2 others were marginally significant) (Table 1). Budd had higher values than Carkeek for richness of all recruits in August and for recruit abundance in August and October (Fig. 2a,b). Carkeek had more clam species than Budd in October. In half the analyses there was a significant Beach (Site) effect, showing high beach-to-beach variation.

When Sediment treatments were pooled and the Brown beaches included for tests of an overall Site effect, for 8 of 13 variables and dates there were no significant differences among sites in abundance or richness of recruits or clam richness (Table 1e). In the 5 analyses where there were differences, Budd always had the highest recruitment (e.g. Fig. 2a) except for the number of clam species in October, when Carkeek had more clam species than Budd ( 3 to 4 clam species recruiting vs. 1 to 2 per cylinder at Budd, with Brown intermediate: Table 1e). This general absence of the expected north-south pattern for recruit richness is visible in Fig. 3a, which illustrates June 2005 recruit richness for all the beaches, arranged from south to north. This figure includes recruitment data from native sediment from the 2 addi-

Table 1. (a-d) Results of 2-way nested ANOVAs with factors Sediment (1 df) and Site (1 df), and Beach nested within Site (4 df). (e) Sediment treatments pooled, 1-way ANOVAs testing Site effects (2 df) and Beaches nested within Site (6 df). Bold emphasises $p \leq 0.05$. Pairwise (Bonferroni) test results: $>=p<0.05$,

$$
\gg=\mathrm{p}<0.01
$$

\begin{tabular}{|c|c|c|c|c|c|}
\hline \multicolumn{2}{|c|}{ Statistical parameters } & Sediment & Site & $\begin{array}{l}\text { Sediment } \times \\
\text { Site }\end{array}$ & $\begin{array}{c}\text { Beach } \\
\text { (Site) }\end{array}$ \\
\hline \multicolumn{6}{|c|}{ (a) Recruit richness (all infauna) } \\
\hline June & $\begin{array}{l}F \\
\mathrm{p}\end{array}$ & $\begin{array}{l}1.150 \\
0.344\end{array}$ & $\begin{array}{l}0.126 \\
0.741\end{array}$ & $\begin{array}{l}4.844 \\
0.093\end{array}$ & $\begin{array}{l}3.983 \\
0.007\end{array}$ \\
\hline July & $\begin{array}{l}F \\
\mathrm{p}\end{array}$ & $\begin{array}{l}2.806 \\
0.169\end{array}$ & $\begin{array}{l}2.336 \\
0.201\end{array}$ & $\begin{array}{l}1.175 \\
0.339\end{array}$ & $\begin{array}{l}3.049 \\
\mathbf{0 . 0 2 6}\end{array}$ \\
\hline August & $\begin{array}{c}F \\
\mathrm{p} \\
\text { Pairwise }\end{array}$ & $\begin{array}{c}0.529 \\
0.507 \\
\text { Budd } \gg \text { Carkeek }\end{array}$ & $\begin{array}{c}18.382 \\
\mathbf{0 . 0 1 3}\end{array}$ & $\begin{array}{l}0.368 \\
0.577\end{array}$ & $\begin{array}{l}2.363 \\
0.066\end{array}$ \\
\hline October & $\begin{array}{l}F \\
\mathrm{p}\end{array}$ & $\begin{array}{l}0.073 \\
0.801\end{array}$ & $\begin{array}{l}2.925 \\
0.162\end{array}$ & $\begin{array}{l}0.455 \\
0.537\end{array}$ & $\begin{array}{l}0.749 \\
0.564\end{array}$ \\
\hline January & $\begin{array}{l}F \\
\mathrm{p}\end{array}$ & $\begin{array}{l}1.114 \\
0.351\end{array}$ & $\begin{array}{l}5.110 \\
0.087\end{array}$ & $\begin{array}{l}9.733 \\
\mathbf{0 . 0 3 6}\end{array}$ & $\begin{array}{l}3.141 \\
\mathbf{0 . 0 2 4}\end{array}$ \\
\hline \multicolumn{6}{|c|}{ (b) Recruit abundance (all infauna, $[\log +1]$ transformed) } \\
\hline June & $\begin{array}{l}F \\
\mathrm{p}\end{array}$ & $\begin{array}{l}6.491 \\
0.063\end{array}$ & $\begin{array}{l}1.843 \\
0.246\end{array}$ & $\begin{array}{l}5.015 \\
0.089\end{array}$ & $\begin{array}{l}13.598 \\
<\mathbf{0 . 0 0 1}\end{array}$ \\
\hline July & $\begin{array}{l}F \\
\mathrm{p}\end{array}$ & $\begin{array}{l}3.277 \\
0.145\end{array}$ & $\begin{array}{l}5.251 \\
0.084\end{array}$ & $\begin{array}{l}0.023 \\
0.887\end{array}$ & $\begin{array}{l}2.105 \\
0.095\end{array}$ \\
\hline August & $\begin{array}{c}F \\
\mathrm{p} \\
\text { Pairwise }\end{array}$ & $\begin{array}{c}2.881 \\
0.165 \\
\text { Budd } \gg \text { Carkeek }\end{array}$ & $\begin{array}{c}32.120 \\
\mathbf{0 . 0 0 5}\end{array}$ & $\begin{array}{l}0.587 \\
0.486\end{array}$ & $\begin{array}{l}1.255 \\
0.301\end{array}$ \\
\hline October & $\begin{array}{c}F \\
\mathrm{p} \\
\text { Pairwise }\end{array}$ & $\begin{array}{c}1.343 \\
0.311 \\
\text { Budd > Carkeek }\end{array}$ & $\begin{array}{c}20.383 \\
\mathbf{0 . 0 1 1}\end{array}$ & $\begin{array}{l}0.765 \\
0.431\end{array}$ & $\begin{array}{l}1.986 \\
0.112\end{array}$ \\
\hline January & $\begin{array}{l}F \\
\mathrm{p}\end{array}$ & $\begin{array}{l}0.374 \\
0.574\end{array}$ & $\begin{array}{l}2.199 \\
0.212\end{array}$ & $\begin{array}{l}6.640 \\
0.062\end{array}$ & $\begin{array}{l}4.106 \\
\mathbf{0 . 0 0 7}\end{array}$ \\
\hline \multicolumn{6}{|c|}{ (c) Clam species richness } \\
\hline June & $\begin{array}{l}F \\
\mathrm{p}\end{array}$ & $\begin{array}{l}0.040 \\
0.851\end{array}$ & $\begin{array}{l}0.258 \\
0.638\end{array}$ & $\begin{array}{l}1.000 \\
0.374\end{array}$ & $\begin{array}{l}0.980 \\
0.427\end{array}$ \\
\hline August & $\begin{array}{l}F \\
\mathrm{p}\end{array}$ & $\begin{array}{l}1.370 \\
0.307\end{array}$ & $\begin{array}{l}0.440 \\
0.543\end{array}$ & $\begin{array}{l}0.219 \\
0.664\end{array}$ & $\begin{array}{l}4.384 \\
\mathbf{0 . 0 0 4}\end{array}$ \\
\hline October & $\begin{array}{c}F \\
\mathrm{p} \\
\text { Pairwise }\end{array}$ & $\begin{array}{c}0.125 \\
0.742 \\
\text { Carkeek > Budd }\end{array}$ & $\begin{array}{c}11.344 \\
\mathbf{0 . 0 2 8}\end{array}$ & $\begin{array}{l}6.125 \\
0.069\end{array}$ & $\begin{array}{l}0.817 \\
0.521\end{array}$ \\
\hline \multicolumn{6}{|c|}{ (d) Clam abundance } \\
\hline June & $\begin{array}{l}F \\
\mathrm{p}\end{array}$ & $\begin{array}{l}0.363 \\
0.579\end{array}$ & $\begin{array}{l}0.749 \\
0.436\end{array}$ & $\begin{array}{l}0.933 \\
0.389\end{array}$ & $\begin{array}{c}7.997 \\
<\mathbf{0 . 0 0 1}\end{array}$ \\
\hline August & $\begin{array}{l}F \\
\mathrm{p}\end{array}$ & $\begin{array}{l}0.013 \\
0.916\end{array}$ & $\begin{array}{l}0.001 \\
0.971\end{array}$ & $\begin{array}{l}0.998 \\
0.374\end{array}$ & $\begin{array}{l}2.876 \\
\mathbf{0 . 0 3 3}\end{array}$ \\
\hline October & $\begin{array}{l}F \\
\mathrm{p}\end{array}$ & $\begin{array}{l}1.229 \\
0.330\end{array}$ & $\begin{array}{l}0.895 \\
0.398\end{array}$ & $\begin{array}{l}11.878 \\
\mathbf{0 . 0 2 6}\end{array}$ & $\begin{array}{l}1.875 \\
0.130\end{array}$ \\
\hline
\end{tabular}


Table 1 (continued)

\begin{tabular}{|c|c|c|c|}
\hline \multicolumn{2}{|c|}{ Statistical parameters } & Site & Beach (Site) \\
\hline \multicolumn{4}{|c|}{$\begin{array}{l}\text { (e) Sediment types pooled, Sites include Brown } \\
\text { Total recruit abundance }\end{array}$} \\
\hline June & $\begin{array}{l}F \\
\mathrm{p}\end{array}$ & $\begin{array}{l}3.783 \\
0.087\end{array}$ & $\begin{array}{c}1.819 \\
<\mathbf{0 . 0 0 1}\end{array}$ \\
\hline July & $\begin{array}{l}F \\
\mathrm{p}\end{array}$ & $\begin{array}{l}3.795 \\
0.086\end{array}$ & $\begin{array}{c}5.357 \\
<\mathbf{0 . 0 0 1}\end{array}$ \\
\hline August & $\begin{array}{c}F \\
\mathrm{p} \\
\text { Pairwise }\end{array}$ & $\begin{array}{c}21.381 \\
\mathbf{0 . 0 0 2} \\
\text { Budd }>\text { Carkeek }=\text { Brown }\end{array}$ & $\begin{array}{r}1.408 \\
0.225 \\
\end{array}$ \\
\hline October & $\begin{array}{c}F \\
\mathrm{p} \\
\text { Pairwise }\end{array}$ & $\begin{array}{c}18.814 \\
\mathbf{0 . 0 0 3} \\
\text { Budd } \gg \text { Carkeek }=\text { Brown }\end{array}$ & $\begin{array}{r}1.613 \\
0.158 \\
\mathrm{n}\end{array}$ \\
\hline January & $\begin{array}{l}F \\
\mathrm{p}\end{array}$ & $\begin{array}{l}0.971 \\
0.431\end{array}$ & $\begin{array}{l}4.280 \\
\mathbf{0 . 0 0 1}\end{array}$ \\
\hline \multicolumn{4}{|c|}{ Total infauna richness } \\
\hline June & $\begin{array}{l}F \\
\mathrm{p}\end{array}$ & $\begin{array}{l}3.061 \\
0.121\end{array}$ & $\begin{array}{c}11.778 \\
\mathbf{0 . 0 1 9}\end{array}$ \\
\hline July & $\begin{array}{l}F \\
\mathrm{p}\end{array}$ & $\begin{array}{l}1.253 \\
0.351\end{array}$ & $\begin{array}{l}6.008 \\
<\mathbf{0 . 0 0 1}\end{array}$ \\
\hline August & $\begin{array}{c}F \\
\mathrm{p} \\
\text { Pairwise }\end{array}$ & $\begin{array}{c}15.208 \\
\mathbf{0 . 0 0 4} \\
\text { Budd }>\text { Brown }=\text { Carkeek }\end{array}$ & $\begin{array}{r}1.958 \\
0.084 \\
\mathrm{k}\end{array}$ \\
\hline October & $\begin{array}{c}F \\
\mathrm{p} \\
\text { Pairwise }\end{array}$ & $\begin{array}{c}6.195 \\
\mathbf{0 . 0 3 5} \\
\text { Budd }>\text { Carkeek }>\text { Brown }\end{array}$ & $\begin{array}{r}0.551 \\
0.768 \\
\end{array}$ \\
\hline January & $\begin{array}{l}F \\
\mathrm{p}\end{array}$ & $\begin{array}{l}2.632 \\
0.151\end{array}$ & $\begin{array}{l}2.673 \\
\mathbf{0 . 0 2 3}\end{array}$ \\
\hline June & $\begin{array}{l}\text { ruit richnes: } \\
\qquad \begin{array}{l}F \\
\mathrm{p}\end{array}\end{array}$ & $\begin{array}{l}0.240 \\
0.794\end{array}$ & $\begin{array}{l}0.838 \\
0.545\end{array}$ \\
\hline August & $\begin{array}{l}F \\
\mathrm{p}\end{array}$ & $\begin{array}{l}0.343 \\
0.723\end{array}$ & $\begin{array}{l}4.408 \\
\mathbf{0 . 0 0 2}\end{array}$ \\
\hline October & $\begin{array}{c}F \\
\mathrm{p} \\
\text { Pairwise }\end{array}$ & $\begin{array}{c}7.461 \\
\mathbf{0 . 0 2 4} \\
\text { Carkeek }>\text { Brown }=\text { Budd }\end{array}$ & $\begin{array}{r}0.666 \\
0.677 \\
\mathrm{~d}\end{array}$ \\
\hline
\end{tabular}

tional sites sampled that month. A regression analysis of richness versus latitude gave an $\mathrm{r}^{2}$ value of 0.04 ( $\mathrm{p}=$ 0.41). Fig. 3b illustrates the contrasting recruit/adult richness patterns; it shows richness of recruits per beach over the whole year, and data for adult infaunal species richness in unmanipulated sediment (from June 2004 and 2005) pooled to the same taxonomic levels as the recruit data. Normandy and West recruit richness is low because these sites were only sampled in 1 mo rather than 9. Adult richness is clearly higher in the north; regressions of richness versus latitude had $\mathrm{r}^{2}$ values of 0.51 (in 2004) and 0.62 (in 2005), both p < 0.001 . There is no correlation between adult (2005 data) and recruit richness $\left(\mathrm{r}^{2}<0.01\right)$.

Multivariate analyses of the assemblages of taxa recruiting into experimental cylinders (abundances of all species square-root transformed and with sediment types pooled) show substantial variation among sites and months (Fig. 4a). Two-way ANOSIM analyses of these data show significant groupings both by Site $(R=0.80$, $p=0.001)$ and Month $(R=0.72, p=0.001)$. Similarities of recruits among sites within a month were fairly high in the summer and fall-winter, with June-August points clustered in the upper right of the plot and fall-winter points in the center. For example, most July samples were dominated by Armandia, hesionids, Platynereis, and Macoma inquinata, while most October samples had hesionids, Rochefortia, and Tellina modesta. Bray-Curtis similarities among sites within months (June to February) ranged from $53 \%$ to $62 \%$ (SIMPER routine). In the spring (April and May), however, sites had quite different recruit assemblages, as indicated by the scattering of those points in Fig. 4a, and similarities were only 41 to $46 \%$. No beaches showed a cyclical pattern where spring 2006 assemblages became similar to spring 2005 assemblages (also seen in Fig. 2), as should have been the case if timing and extent of recruitment were predictable seasonally from year to year.

In June 2005, assemblages of taxa recruiting into unmanipulated sediment at the Normandy and West sites were similar to those in the experimental cylinders at nearby beaches (Fig. 4b); Normandy and West recruits grouped especially closely with those at Carkeek, just north of West (Fig. 1). ANOSIM tests showed that the 5 sites differed overall in their assemblages of recruits $(\mathrm{R}=0.53, \mathrm{p}<0.001)$, but not between native sediment samples (Normandy and West) and cylinder samples $(\mathrm{R}=0.096, \mathrm{~ns})$. Recruitment into the cylinders at Brown during that period was very low in abundance and diversity (e.g. Fig. 2a,b), causing the Brown points to be outliers.

Multivariate analyses comparing infaunal assemblages (species and abundances) recruiting into cylinders versus those found as adults at each beach showed that overall, these assemblages were clearly different (Fig. 5, also Fig. 3b). Similarities of adult assemblages (pooled into the same taxonomic categories as recruits) were relatively low among beaches (points) within a site (adult points for each site are broadly spread; similarities range from 38 to $58 \%$, SIMPER analyses), and even lower among sites (27 to $45 \%$ ). In contrast, similarities of recruit assemblages were relatively high both among beaches within a site (71 to $80 \%$ ) and among sites (56 to $66 \%$ ); all recruits points are clustered in Fig. 5. A PERMANOVA test found a significant effect of Site $(p=0.001)$ and Treatment (Recruits vs. Adults: $\mathrm{p}=0.001$ ), and a significant interaction $(p=0.007)$ indicating that the similarities between recruits and adults depend upon the site. Recruit-adult similarity was very low at Budd (23\%) (see the separation between Budd adults and recruits in Fig. 5), Brown was intermediate at $35 \%$, and Carkeek was the highest at $50 \%$ (clusters of points were 
a) Recruit richness, June 2005

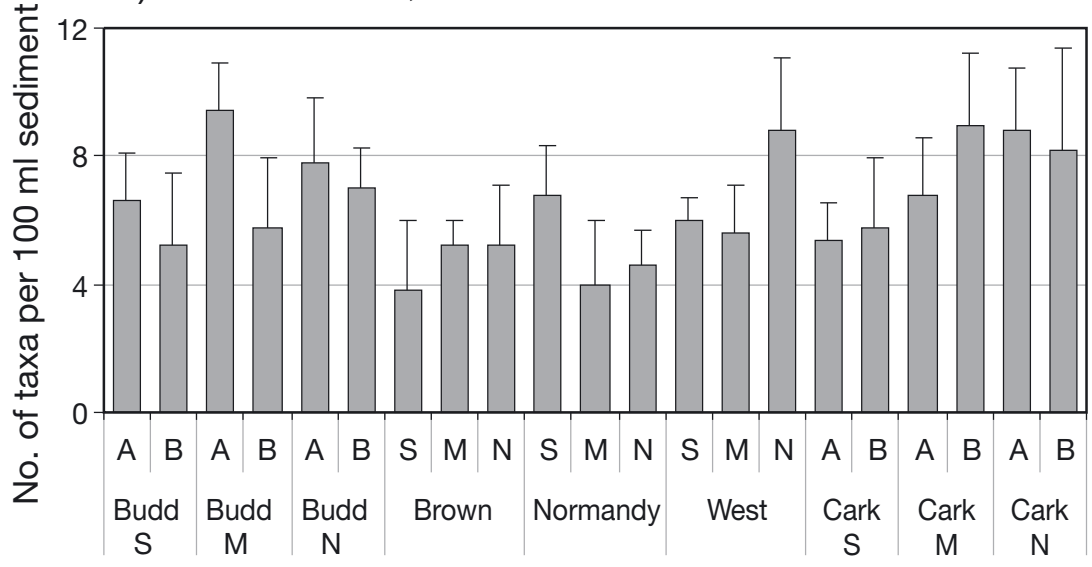

b) Recruit vs. adult richness

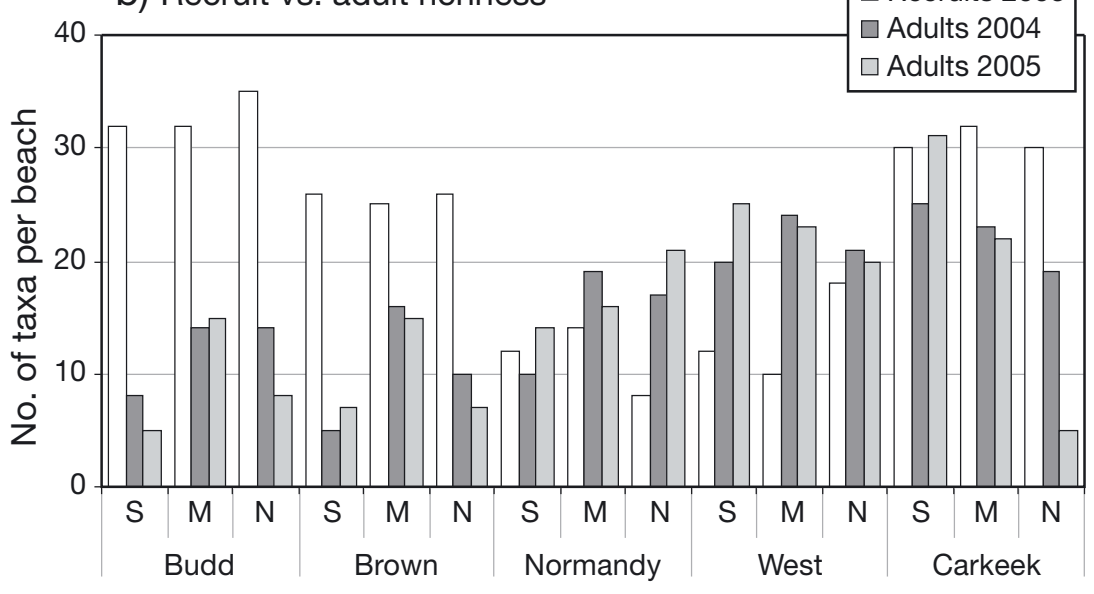

Fig. 3. (a) Number of taxa of recruits found per beach and per sediment type on each sampling date, including in unmanipulated sediment at Normandy and West. Beaches are arranged from south on the left to north on the right. Bars are means + SD from the 5 replicate cylinders per sediment type. Sediment types used: $\mathrm{A}=$ Brown North; $\mathrm{B}=$ Budd North; $\mathrm{S}=$ southern beach at indicated site; $\mathrm{M}=$ middle beach at indicated site; $\mathrm{N}=$ northern beach at indicated site. Only 1 sediment type (Brown North source) was used at Brown. Cark $=$ Carkeek. (b) Number of taxa per beach of recruits found over all 9 sampling periods (in 2005 to 2006) and of adult infauna found on a transect at the same beaches. Adult richness is given for the 2 yr when all 15 beaches were sampled (2004 \& 2005; Normandy \& West were not sampled in 2006). Adult data are pooled into the same taxonomic levels as the recruits (Appendix 1) a) Recruit assemblages by month

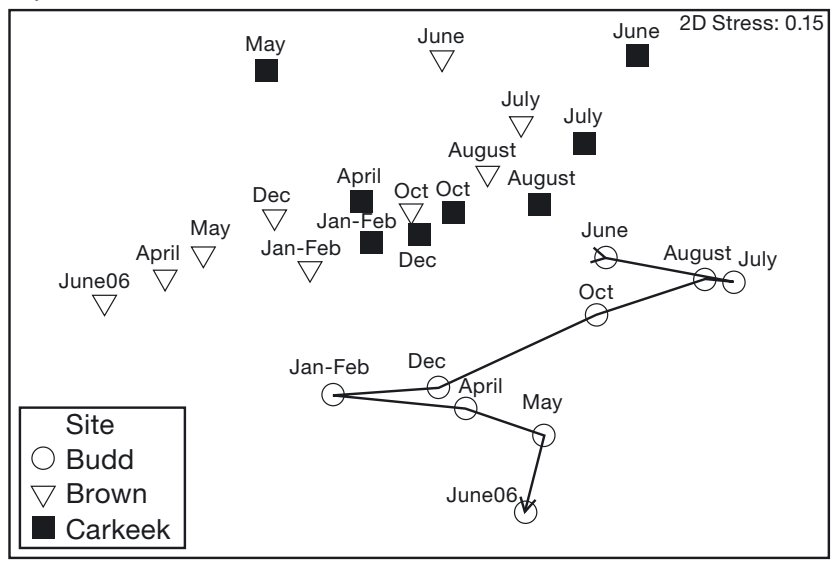

b) Recruits at 5 sites, June 2005

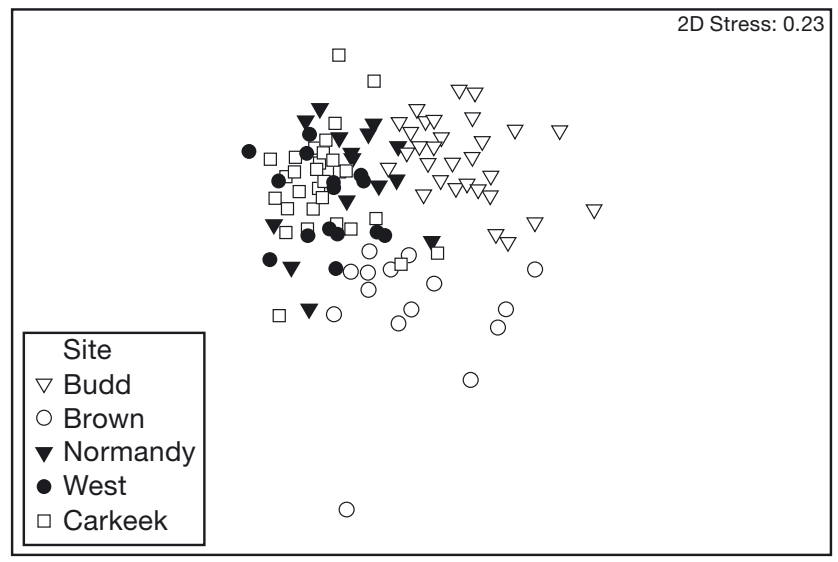

Fig. 4. (a) Non-metric multidimensional scaling plot of assemblages of recruits at each beach on all 9 sampling dates (June 2005 to June 2006, sediment treatments pooled, data averaged among the 3 beaches per site). Points close together indicate great similarity of assemblages (taxa and abundances). Abundances were square-root transformed to reduce the weighting of very abundant taxa. The example overlay trajectory shown for Budd illustrates the dissimilarity between recruits of June 2006 and June 2005. (b) Multidimensional scaling plot comparing recruits in experimental cylinders at 3 sites (Budd, Brown, Carkeek) with recruits in ambient sediment at 2 nearby sites (Normandy, West) in June 2005. Each point represents the assemblage from 1 cylinder or sample, not averaged over replicates and beaches as in (a) 
Recruits (mean of all months) vs. adult infauna (June)

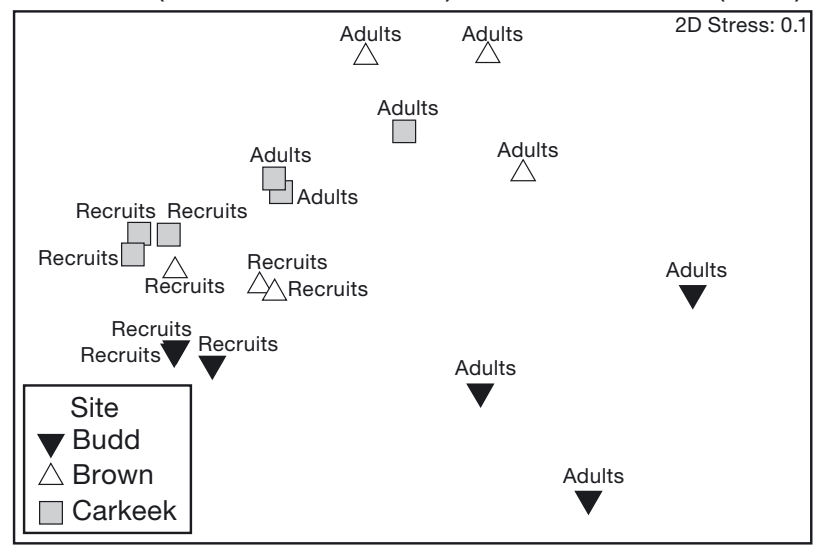

Fig. 5. Non-metric multidimensional scaling plot of assemblages of recruits in experimental cylinders, averaged over all 9 sampling dates, versus adults at the same sites, sampled in June 2005 and June 2006. Each point = averaged value from 1 beach

relatively close). Thus while all adult assemblages diverged from their local recruits, this divergence was most extreme at Budd and least extreme at Carkeek. Even when data were reduced to presence/absence per beach to eliminate differences in abundance, the same patterns visible in Fig. 5 remain (not illustrated). Table 2 lists the taxa contributing to the dissimilarities between recruits and adults for each site. Only a few taxa were represented mostly by adults and seldom by recruits, while many taxa were more common as recruits. At Budd, 9 taxa were seen as recruits but never as adults, at Brown 7 taxa, and at Carkeek none.

Total abundances of recruits versus adults per core were compared for the 2 most common groups of organisms, polychaetes and clams (Fig. 6). Other taxa (echinoderms, phoronids, anemones) always averaged $<1$ individual per core in both datasets. As suggested by the multivariate analyses, the biggest changes in abundances from recruits to adults occurred at Budd beaches, which had very large numbers of recruits but low adult densities. At Brown and Carkeek, adult densities for both taxa tended to reflect recruit densities, with adult densities being particularly high at Carkeek beaches.
Table 2. Species appearing in SIMPER analyses as contributing $>2 \%$ to dissimilarities between adult and recruit communities per site. Values are percent contributions to dissimilarity at that site. Cells without a value or with '-' contributed $\leq 2 \%$ to disimilarity at that site. ${ }^{\mathrm{R}}$ Taxon was found as recruits but never as adults and ${ }^{\mathrm{A}}$ Taxon was present more often as adults than recruits, at that site

\begin{tabular}{|lccc|}
\hline & Budd & Brown & Carkeek \\
\hline Dorvilleids & - & $\mathrm{R}$ & - \\
Goniadids & $3^{\mathrm{R}}$ & $\mathrm{R}$ & - \\
Orbiniids & 2 & - & - \\
Phyllodocids & 6 & $2^{\mathrm{R}}$ & - \\
Hesionids (other) & $19^{\mathrm{R}}$ & $10^{\mathrm{R}}$ & 10 \\
Nereids (other) & - & $3^{\mathrm{A}}$ & - \\
Polynoids & 2 & $\mathrm{R}$ & - \\
Syllids & - & $\mathrm{R}$ & - \\
Heteropodarke sp. & $\mathrm{R}$ & - & - \\
Microphthalmus hystrix & $4^{\mathrm{R}}$ & - & - \\
Platynereis bicanaliculata & $8^{\mathrm{R}}$ & 3 & - \\
Armandia brevis & 8 & 10 & 13 \\
Boccardiella hamata & $2^{\mathrm{R}}$ & - & - \\
Malacoceros glutaeus & - & - & 5 \\
Polydora sp. & $\mathrm{R}$ & - & - \\
Prionospio steenstrupi & $\mathrm{R}$ & $5^{\mathrm{R}}$ & 3 \\
Spio filicornis & - & - & $4^{\mathrm{A}}$ \\
Rochefortia tumida & $11^{\mathrm{R}}$ & 13 & 8 \\
Macoma inquinata & 7 & 4 & $3^{\mathrm{A}}$ \\
Tellina modesta & 3 & 6 & 4 \\
Saxidomus giganteus & - & - & $3^{\mathrm{A}}$ \\
Parvilucina tenuisculpta & - & 3 & - \\
Cirratulids & $3^{\mathrm{A}}$ & $2^{\mathrm{A}}$ & $3^{\mathrm{A}}$ \\
Hemipodus borealis & $3^{\mathrm{A}}$ & $12^{\mathrm{A}}$ & $5^{\mathrm{A}}$ \\
Phoronids & - & - & $2^{\mathrm{A}}$ \\
Oweniids & - & $6^{\mathrm{A}}$ & $10^{\mathrm{A}}$ \\
Maldanids & $4^{\mathrm{A}}$ & - & $4^{\mathrm{A}}$ \\
\hline
\end{tabular}

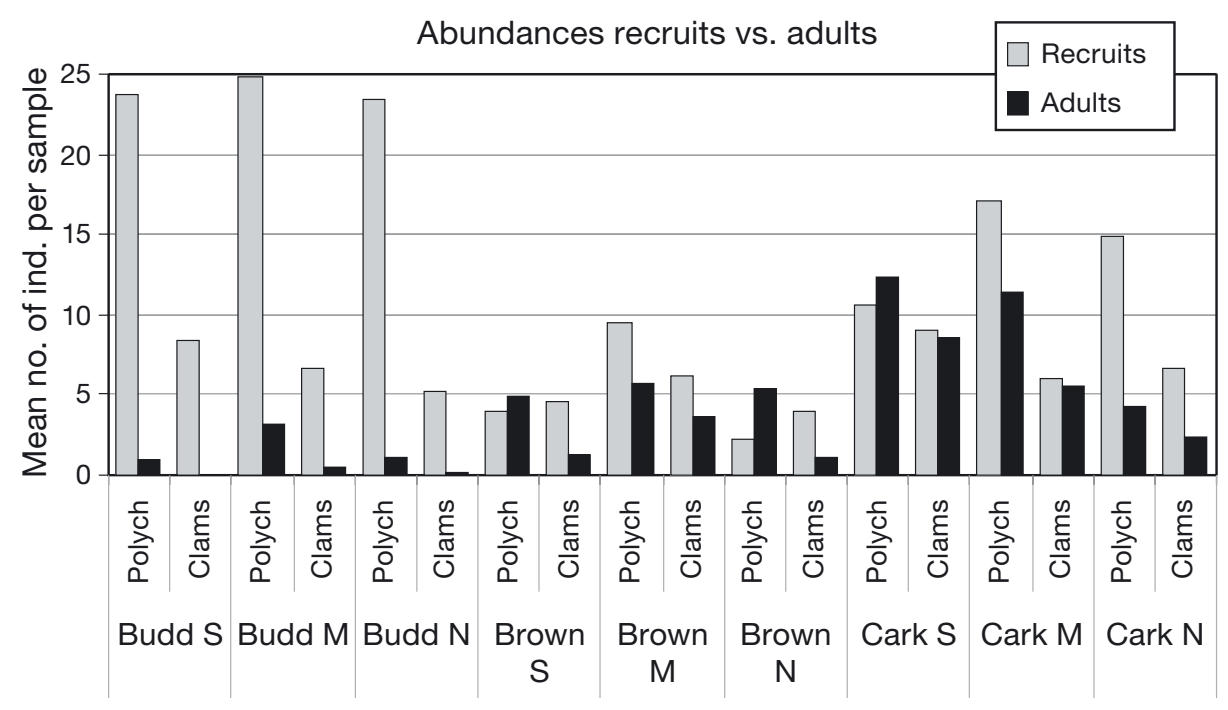

Fig. 6. Comparison of densities of recruits versus adults at each of the 9 sampled beaches. Recruit densities per cylinder were averaged over the 5 to 10 replicates per month and over the 9 sampling months. Adult densities were averaged over the 10 cores sampled each June over 2 yr. Densities of all polychaetes and all clams were summed per sample. S, M, N: see Fig. 3 


\section{DISCUSSION}

Differential recruitment (settlement plus survival up to $6 \mathrm{wk}$ post-settlement) among sites is not the cause of the estuarine clines in diversity and biomass seen in Puget Sound (Dethier \& Schoch 2005, Dethier et al. 2010). Supply of both abundances and species richness of larvae appears to be as high or higher at the innerestuary sites (Figs. 2, $3 \&$ 6, Table 1). If supply-side issues were limiting adult assemblages, the observed recruitment patterns should result in no diversity gradient along the estuarine gradient or even a pattern of higher diversity in the inner estuary. Taxa found recruiting were diverse (Appendix 1), of different lifehistory types and trophic categories. Only a few taxa that were present as adults in undisturbed assemblages were absent from the recruit samples, but many taxa of recruits were absent as adults.

Possibly, recruitment patterns over the sampled year were not typical, i.e. in other years recruitment might have been higher in the outer-estuary sites, thus generating the pattern seen in the adult infauna. This possibility might be especially likely if the infauna were all long-lived and thus retained distribution patterns established under different conditions, but that is not consistently the case for this fauna. Life histories of the infauna in these beaches are in many cases poorly understood but are likely diverse, ranging from polychaetes with high turnover rates to clams that live for several years. Species with high turnover rates such as the polychaete Armandia would be predicted to appear commonly as recruits, as was the case in the present study (Appendix 1), but might not persist to be common as adults. The qualitative or quantitative differences between assemblages of recruits and adults cannot be attributed to these life-history differences, however. At the northern (more marine) sites, all species seen as recruits (at any time during the year) were also seen as adults in at least 1 of the June samples. In contrast, at the more estuarine beaches, 8 polychaete and 1 bivalve taxa were found as recruits but never as adults. Multivariate analyses using presence/absence data, i.e. discounting abundance differences between recruits and adults that might arise in high-turnover taxa, still showed that the more estuarine sites suffered much greater loss of taxa to post-recruitment processes than did the more marine sites. A wide variety of benthic infaunal organisms thus recruit to beaches throughout Puget Sound, but many of them only persist in the north.

The experimental design controlled a number of potentially confounding variables. I anticipated that substrate differences (e.g. organic content, grain size) might be critical in larval settlement or very early survival for infauna, but sediment types were controlled by using common sediment sources. Adult-larvae interactions can also be important to recruitment, but this variable was largely controlled by the use of defaunated sediment and short time intervals. Very few large $(>1 \mathrm{~cm})$ organisms moved into the experimental cylinders, although the sizes of some of the recruits (e.g. small clams) suggested that they had drifted in as juveniles rather than settling in as larvae. While many juvenile infauna are highly mobile and thus may have settled elsewhere and crawled or drifted into the cylinders, this post-larval dispersal is unlikely to span more than hundreds of meters. Despite controlling sediment characteristics and using beaches within $3 \mathrm{~km}$ of each other as replicates, many analyses showed high beachto-beach variation. These among-beach differences could relate to local differences in flow (affecting settlement of larvae out of the plankton or drift of juveniles alongshore), or to uncontrolled variables such as porewater chemistry that deterred settlement behavior or caused mortality prior to the 6 -wk collection intervals.

Examining the scales of variation in recruitment data can provide clues to controlling processes (Roegner et al. 2007, Navarrete et al. 2008). Patterns of temporal variation, such as the moderate consistency in the types and numbers of recruits seen at all sites on a given date (Fig. 4a), suggest that the populations are quite open, with effective dispersal among sites tens of $\mathrm{km}$ apart (Thrush et al. 2008). This is not surprising given that most (at least 34 out of the 56 found) taxa apparently have larval stages lasting at least a week (Appendix 1), and strong local tidal currents should allow transit along much of Puget Sound's shoreline (Barnes \& Ebbesmeyer 1978, Moore et al. 2008). It also suggests that any circulation anomalies caused by the underwater sill separating south and central Puget Sound (Dethier \& Schoch 2005, Babson et al. 2006) do not act as a barrier to dispersal, at least for these organisms.

For most recruitment parameters on most dates there were no spatial differences on a regional (among-site) scale (Table 1), again suggesting that these are open populations. Where there were differences, however, their direction was for richness and abundance of infaunal recruitment to be higher in the inner estuary than the outer, with the central site intermediate. A possible explanation is that slightly reduced wave energy (Dethier \& Schoch 2005) or increased retention of larvae in the inner, southern bays of Puget Sound (relative to the more open central and northern areas) provided better conditions for larvae to settle out of the plankton. Wu \& Shin (1997) similarly found that among-site differences in recruitment to sterilized sediment were greater than among-sediment differences (sand vs. mud), and hypothesized that local availability of propagules was critical. 
The composition of adult assemblages, however, is clearly responding to different processes than those controlling settlement or very early survival. Spatial patterns of variation in abundance and diversity of recruits did not persist to create matching patterns of variation in adults. The multivariate analyses showed that recruit assemblages are more similar to adult assemblages in the north than in the south, with central sites intermediate. In the period of growth between recruits (captured on $100 \mu \mathrm{m}$ sieves) and adults (on $2 \mathrm{~mm}$ sieves), communities in the inner estuary, in particular, undergo considerable change-loss of species and reduction in abundances. Related research efforts suggest that growth rates per se are not lower in the south, and in fact are higher for some species (Ruesink unpubl. data). My results strongly implicate early selective mortality towards the southern/inner end of this estuarine gradient. Hypotheses about this mortality are under investigation. Logical alternatives include: adult-juvenile interactions, known to be especially important when adult assemblages include predators and deposit feeders (reviewed in Olafsson et al. 1994); pollution (possibly higher in the south, with more sources of pollutants and poorer circulation); and physical stresses. Unlike in many estuaries, the physical gradients in Puget Sound are relatively subtle, with mean salinities only varying by ca. 4 psu and mean temperatures by only $2^{\circ} \mathrm{C}$ (Dethier \& Schoch 2005, Dethier et al. 2010), although local extremes may be greater. Ultimately, some combination of these factors, rather than recruitment limitation, must be responsible for the low richness, abundance, and biomass of intertidal infauna at the more estuarine end of this system.

Acknowledgements. This project received indispensable help from H. Berry, J. Ruesink, A.G. Sprenger, B. Reeves, and especially A. Galloway. Additional assistance was provided by C. Schoch, M. Vasquez, K. Sprenger, and DNR and UW volunteers. S. Woodin provided invaluable advice on methods. P. Peterson and 2 anonymous reviewers significantly $(\mathrm{p}<$ 0.01) improved the manuscript. Facilities at the Friday Harbor Laboratories were provided by the Director. This research was funded in part by a grant from the Washington Sea Grant Program, University of Washington, pursuant to National Oceanic and Atmospheric Administration Award No. R/ES57. The views expressed herein are those of the author and do not necessarily reflect the views of NOAA or any of its subagencies. Matching funds were generously provided by the Washington Department of Natural Resources. The experiments comply with current laws of the USA.

\section{LITERATURE CITED}

Babson AL, Kawase M, MacCready P (2006) Seasonal and interannual variability in the circulation of Puget Sound, Washington: a box model study. Atmos-ocean 44:29-45

Barnes CA, Ebbesmeyer CC (1978) Some aspects of Puget Sound's circulation and water properties. In: Kjerfve B (ed)
Estuarine Transport Processes. Univ. of South Carolina Press, Columbia, SC, p 209-228

Bellgrove A, Clayton MN, Quinn GP (1997) Effects of secondarily treated sewage effluent on intertidal macroalgal recruitment processes. Mar Freshw Res 48:137-146

Beukema JJ, Dekker R (2005) Decline of recruitment success in cockles and other bivalves in the Wadden Sea: possible role of climate change, predation on postlarvae and fisheries. Mar Ecol Prog Ser 287:149-167

Blanchette CA, Gaines SD (2007) Distribution, abundance, size and recruitment of the mussel, Mytilus californianus, across a major oceanographic and biogeographic boundary at Point Conception, California, USA. J Exp Mar Biol Ecol 340:268-279

Caley MJ, Carr MH, Hixon MA, Hughes TP, Jones GP, Menge BA (1996) Recruitment and the local dynamics of open marine populations. Annu Rev Ecol Syst 27:477-500

Dethier MN, Schoch GC (2005) The consequences of scale: assessing the distribution of benthic populations in a complex estuarine fjord. Estuar Coast Shelf Sci 62:253-270

- Dethier MN, Ruesink JL, Berry H, Sprenger AG, Reeves B (2010) Restricted ranges in physical factors may constitute subtle stressors for estuarine biota. Mar Environ Res 69: $240-247$

$>$ Fraschetti S, Giangrande A, Terlizzi A, Boero F (2002) Preand post-settlement events in benthic community dynamics. Oceanol Acta 25:285-295

Freidenburg TL, Menge BA, Halpin PM, Webster J, SuttonGrier A (2007) Cross-scale variation in top-down and bottom-up control of algal abundance. J Exp Mar Biol Ecol $347: 8-29$

> Hockin DC (1982) The effects of sediment particle diameter upon the meiobenthic copepod community on an intertidal beach: a field and laboratory experiment. J Anim Ecol 51:555-572

> Hunt HL, McLean DA, Mullineaux LS (2003) Post-settlement alteration of spatial patterns of soft shell clam (Mya arenaria) recruits. Estuaries 26:72-81

- Hunt HL, Maltais MJ, Fugate DC, Chant RJ (2007) Spatial and temporal variability in juvenile bivalve dispersal: effects of sediment transport and flow regime. Mar Ecol Prog Ser 352:145-159

Jennings LB, Hunt HL (2009) Distances of dispersal of juvenile bivalves (Mya arenaria (Linnaeus), Mercenaria mercenaria (Linnaeus), Gemma gemma (Totten)). J Exp Mar Biol Ecol 376:76-84

> Labrune C, Gremare A, Guizien K, Amouroux JM (2007) Long-term comparison of soft bottom macrobenthos in the Bay of Banyuls-sur-Mer (north-western Mediterranean Sea): a reappraisal. J Sea Res 58:125-143

Lenihan HS, Peterson CH, Kim SL, Conlan KE and others (2003) Variation in marine benthic community composition allows discrimination of multiple stressors. Mar Ecol Prog Ser 261:63-73

> Lu L, Wu RSS (2006) A field experimental study on recolonization and succession of macrobenthic infauna in defaunated sediment contaminated with petroleum hydrocarbons. Estuar Coast Shelf Sci 68:627-634

$>$ Lu L, Wu RSS (2007) Seasonal effects on recolonization of macrobenthos in defaunated sediment: a series of field experiments. J Exp Mar Biol Ecol 351:199-210

Lundquist CJ, Thrush SF, Oldman JW, Senior AK (2004) Limited transport and recolonization potential in shallow tidal estuaries. Limnol Oceanogr 49:386-395

> Lundquist CJ, Thrush SF, Hewitt JE, Halliday J, MacDonald I, Cummings VJ (2006) Spatial variability in recolonisation potential: influence of organism behaviour and hydro- 
dynamics on the distribution of macrofaunal colonists. Mar Ecol Prog Ser 324:67-81

Marinelli RL, Woodin SA (2004) Disturbance and recruitment: a test of solute and substrate specificity using Mercenaria mercenaria and Capitella sp. 1. Mar Ecol Prog Ser 269: 209-221

Moore SK, Mantua NJ, Newton JA, Kawase M, Warner MJ, Kellogg JP (2008) A descriptive analysis of temporal and spatial patterns of variability in Puget Sound oceanographic properties. Estuar Coast Shelf Sci 80:545-554

Navarrete SA, Broitman BR, Menge BA (2008) Interhemispheric comparison of recruitment to intertidal communities: pattern persistence and scales of variation. Ecology 89:1308-1322

Negrello Filho OA, Underwood AJ, Chapman MG (2006) Recolonization of infauna on a tidal flat: an experimental analysis of modes of dispersal. J Exp Mar Biol Ecol 328: $240-250$

Olafsson EB, Peterson CH, Ambrose WG Jr (1994) Does recruitment limitation structure populations and communities of macro-invertebrates in marine soft sediments: the relative significance of pre-and post-settlement processes. Oceanogr Mar Biol Annu Rev 32:65-109

Peterson CH (1979) Predation, competitive exclusion, and diversity in the soft-sediment benthic communities of estuaries and lagoons. In: Livingston RJ (ed) Ecological processes in coastal and marine ecosystems. Plenum, New York, NY

Peterson CH (1982) The importance of predation and intraand interspecific competition in the population biology of two infaunal suspension-feeding bivalves, Protothaca staminea and Chione undatella. Ecol Monogr 52:437-475

Pillay D, Branch GM, Forbes AT (2007) Effects of Callianassa kraussi on microbial biofilms and recruitment of macrofauna: a novel hypothesis for adult-juvenile interactions. Mar Ecol Prog Ser 347:1-14

Reiss H, Kröncke I (2005) Seasonal variability of infaunal community structure in three areas of the North Sea under different environmental conditions. Estuar Coast Shelf Sci 65:253-274

Rilov G, Dudas SE, Menge BA, Grantham BA, Lubchenco J, Schiel DR (2008) The surf zone: a semi-permeable barrier to onshore recruitment of invertebrate larvae? J Exp Mar Biol Ecol 361:59-74

Roegner GC, Armstrong DA, Shanks AL (2007) Wind and tidal influences on larval crab recruitment to an Oregon estuary. Mar Ecol Prog Ser 351:177-188

Shull DH (1997) Mechanisms of infaunal polychaete dispersal and colonization in an intertidal sandflat. J Mar Res 55: 153-179

Sigurdsson JB, Titman CW, Davies PA (1976) The dispersal of young post-larval bivalve molluscs by byssal threads. Nature 262:386-387

Smith CR, Brumsickle SJ (1989) The effects of patch size and substrate isolation on colonization modes and rates in an intertidal sediment. Limnol Oceanogr 34:1263-1277

Snelgrove PV, Butman CA (1994) Animal-sediment relationships revisited: cause vs. effect. Oceanogr Mar Biol Annu Rev 32:111-177

St-Onge P, Miron G (2007) Effects of current speed, shell length and type of sediment on the erosion and transport of juvenile softshell clams (Mya arenaria). J Exp Mar Biol Ecol 349:12-26

Stark JS, Riddle MJ, Smith SDA (2004) Influence of an Antarctic waste dump on recruitment to nearshore marine soft-sediment assemblages. Mar Ecol Prog Ser 276:53-70

Strathmann MF (1987) Reproduction and development of marine invertebrates of the northern Pacific Coast. University of Washington Press, Seattle

Thomsen MS, Silliman BR, McGlathery KJ (2007) Spatial variation in recruitment of native and invasive sessile species onto oyster reefs in a temperate soft-bottom lagoon. Estuar Coast Shelf Sci 72:89-101

Thrush SF, Halliday J, Hewitt JE, Lohrer AM (2008) The effects of habitat loss, fragmentation, and community homogenization on resilience in estuaries. Ecol Appl 18: $12-21$

Whitlatch RB, Lohrer AM, Thrush SF, Pridmore RD, Hewitt JE, Cummings VJ, Zajac RN (1998) Scale-dependent benthic recolonization dynamics: life stage-based dispersal and demographic consequences. Hydrobiologia 375-376: $217-226$

> Wing SR, Botsford LW, Morgan LE, Diehl JM, Lundquist CJ (2003) Inter-annual variability in larval supply to populations of three invertebrate taxa in the northern California Current. Estuar Coast Shelf Sci 57:859-872

- Wu RSS, Shin PKS (1997) Sediment characteristics and colonization of soft-bottom benthos: a field manipulation. Mar Biol 128:475-487

Appendix 1. Taxa identified as recruits, and lifestyle categories. In 'Trophic': $\mathrm{C}=$ carnivore, $\mathrm{O}=$ omnivore, $\mathrm{SDF}=$ surface deposit feeder, $\mathrm{SSD}=$ subsurface deposit feeder, Susp = suspension feeder, and $\mathrm{H}=$ herbivore. For 'Larval life': B = benthic development, VS = very short ( $<1 \mathrm{~d}$ in plankton), $\mathrm{S}=$ short ( 1 to $7 \mathrm{~d}), \mathrm{M}=$ medium ( 7 to $14 \mathrm{~d}), \mathrm{L}=$ long ( $>14 \mathrm{~d}), \mathrm{U}=$ unknown. Many of these designations were based on extrapolations from related taxa or from descriptions of planktonic larvae

\begin{tabular}{|lcclc|}
\hline Taxon identified & Trophic & $\begin{array}{c}\text { Larval } \\
\text { life }\end{array}$ & Family & $\begin{array}{c}\text { No. of } \\
\text { individuals }\end{array}$ \\
\hline Polychaetes & & & & \\
$\quad$ Ampharetids & SDF & S & Ampharetidae & 6 \\
Capitellids & SSD & U & Capitellidae & 23 \\
Chrysopetalids & C & M & Chrysopetalidae & 190 \\
Cirratulids & SDF & U & Cirratulidae & 45 \\
Dorvilleids & O & M & Dorvilleidae & 24 \\
Hemipodus borealis & C & M & Glyceridae & 457 \\
\hline
\end{tabular}


Appendix 1 (continued)

\begin{tabular}{|c|c|c|c|c|}
\hline Taxon identified & Trophic & $\begin{array}{l}\text { Larval } \\
\text { life }\end{array}$ & Family & $\begin{array}{c}\text { No. of } \\
\text { individuals }\end{array}$ \\
\hline \multicolumn{5}{|l|}{ Polychaetes } \\
\hline Goniadids & $\mathrm{C}$ & $\mathrm{L}$ & Goniadidae & 311 \\
\hline Hesionids (other) & $\mathrm{C}$ & M & Hesionidae & 3537 \\
\hline Heteropodarke sp. & $\mathrm{C}$ & M & Hesionidae & 9 \\
\hline Microphthalmus hystrix & SSD & B & Hesionidae & 305 \\
\hline Nephytids & $\mathrm{C}$ & M & Nephtyidae & 47 \\
\hline Nereis procera & $\mathrm{O}$ & M & Nereidae & 7 \\
\hline Platynereis bicanaliculata & $\mathrm{O}$ & $\mathrm{L}$ & Nereidae & 615 \\
\hline Nerilla & SSD & $\mathrm{U}$ & Nerillidae & 122 \\
\hline Armandia brevis & SSD & $\mathrm{L}$ & Opheliidae & 4050 \\
\hline Orbiniids & SSD & $\mathrm{S}$ & Orbiniidae & 116 \\
\hline Pholoe minuta & $\mathrm{C}$ & M & Pholoidae & 6 \\
\hline Phyllodocids & $\mathrm{C}$ & $\mathrm{L}$ & Phyllodocidae & 367 \\
\hline Polynoids & $\mathrm{C}$ & $\mathrm{L}$ & Polynoidae & 129 \\
\hline Boccardiella hamata & SDF & $\mathrm{L}$ & Spionidae & 56 \\
\hline Malacoceros glutaeus & SDF & M & Spionidae & 224 \\
\hline Polydora sp. & SDF & M & Spionidae & 30 \\
\hline Prionospio steenstrupi & SDF & M & Spionidae & 143 \\
\hline Spio filicornis & SDF & M & Spionidae & 48 \\
\hline Syllids & $\mathrm{C}$ & $\mathrm{U}$ & Syllidae & 41 \\
\hline \multicolumn{5}{|l|}{ Bivalves } \\
\hline Pododesmus macrochisma & Susp & $\mathrm{L}$ & Anomiidae & 1 \\
\hline Clinocardium nuttallii & Susp & $\mathrm{L}$ & Cardiidae & 114 \\
\hline Hiatella arctica & Susp & $\mathrm{U}$ & Hiatellidae & 8 \\
\hline Parvilucina tenuisculpta & Susp & $\mathrm{U}$ & Lucinidae & 24 \\
\hline Tresus сарах & Susp & $\mathrm{L}$ & Mactridae & 61 \\
\hline Rochefortia tumida & Susp & $\mathrm{L}$ & Montacutidae & 1831 \\
\hline Mytilus trossulus & Susp & $\mathrm{L}$ & Mytilidae & 30 \\
\hline Acila & SDF & $\mathrm{M}$ & Nuculidae & 4 \\
\hline Macoma inquinata & SDF & $\mathrm{L}$ & Tellinidae & 1354 \\
\hline Pink unknown tellinid & Susp & $\mathrm{U}$ & Tellinidae & 4 \\
\hline Tellina modesta & SDF & $\mathrm{L}$ & Tellinidae & 396 \\
\hline Ribbed unknown clams & Susp & $\mathrm{U}$ & Unknown & 2 \\
\hline Small unknown clams & Susp & $\mathrm{U}$ & Unknown & 504 \\
\hline Protothaca staminea & Susp & $\mathrm{L}$ & Veneridae & 170 \\
\hline Saxidomus giganteus & Susp & $\mathrm{L}$ & Veneridae & 301 \\
\hline Nutricola tantilla & Susp & B & Veneridae & 32 \\
\hline Venerupis philippinarum & Susp & $\mathrm{L}$ & Veneridae & 2 \\
\hline \multicolumn{5}{|l|}{ Other } \\
\hline Haminoea & $\mathrm{H}$ & B & $\begin{array}{l}\text { Atyidae } \\
\text { (Mollusca) }\end{array}$ & 3 \\
\hline Crepidula dorsata & Susp & $\mathrm{L}$ & $\begin{array}{l}\text { Calyptraeidae } \\
\text { (Mollusca) }\end{array}$ & 4 \\
\hline Crepidula fornicata & Susp & $\mathrm{L}$ & $\begin{array}{l}\text { Calyptraeidae } \\
\text { (Mollusca) }\end{array}$ & 1 \\
\hline Crepidula undet. & Susp & $\mathrm{L}$ & $\begin{array}{l}\text { Calyptraeidae } \\
\text { (Mollusca) }\end{array}$ & 6 \\
\hline Dendraster excentricus & SDF & $\mathrm{L}$ & $\begin{array}{l}\text { Dendrasteridae } \\
\text { (Echinodermata) }\end{array}$ & 154 \\
\hline Edwardsia sp. & Susp & $\mathrm{L}$ & $\begin{array}{l}\text { Edwardsiidae } \\
\text { (Cnidaria) }\end{array}$ & 1 \\
\hline Polinices & $\mathrm{C}$ & VS & $\begin{array}{l}\text { Naticidae } \\
\text { (Mollusca) }\end{array}$ & 6 \\
\hline Ophiuroids & $\mathrm{O}$ & $\mathrm{U}$ & $\begin{array}{l}\text { Ophiuroidea } \\
\text { (Echinodermata) }\end{array}$ & 22 \\
\hline Leptosynapta & SSD & B & $\begin{array}{l}\text { Synaptidae } \\
\text { (Echinodermata) }\end{array}$ & ) \\
\hline Miscellaneous rare $^{a}$ & $\mathrm{O}$ & $\mathrm{U}$ & Unknown & 9 \\
\hline
\end{tabular}

